\title{
THE EVOLUTION OF THE HEADLINE - FROM PRINT TO PATTERNS AND VIRALITY (AN OVERVIEW OF RESEARCH IN ENGLISH AND BULGARIAN)
}

\author{
Radostina Iglikova*
}

\begin{abstract}
The present article deals with the differences between headlines in the media of print and the qualitatively new phenomenon that is the web or online headline. The article begins with an overview of the discussion of the nature of print headlines in both English-language and Bulgarian-language literature and uses this as a platform for introducing the discussion concerning the evolutionary aspect of headlines in the so-called "Digital Era". The study touches upon the role of the World Wide Web as a medium and its influence on user behavior patterns and, in turn, the effect these have on the web headline as such. The specific guidelines introduced by leading researchers in the field of writing for the web are also discussed, as well as their proposed classifications and typologies of headlines online. In this relation the paper discusses the specific models for creating successful headlines online by applying a particular set of patterns, each of which consists of a constant underlying structure and a set of empty slots which allow for customization and variation in each new headline. The use of such repetitive patterns for generating web headlines is also considered for its contributions to linguistic efficiency and the resulting improvement of online user experience. In addition, the article offers a discussion of recent findings concerning the specific development known as "virality" and more specifically - the so-called "viral headlines" and their specific features.
\end{abstract}

Key words: print headlines, web/online headlines, headline patterns, viral headlines, writing for the web

\section{Introduction}

The present article proposes a discussion of headlines from an evolutionary point of view, focusing in turn on three separate aspects of existing research on the language of headlines - print headlines, pattern-based web headlines and viral web headlines. Since literature on the problem is abundant in English as the language of origin of the Internet and the World Wide Web and, respectively,

* Assist. Professor PhD at Shumen University, Department of English Studies, Shumen, Bulgaria, e-mail: r.iglikova@shu.bg. 
of the web headline as a phenomenon, it is deemed appropriate to enrich and diversify the current overview by employing the author's specific background and including a discussion of existing research in Bulgarian. In addition, the article aims to underscore the relationship between the quality of web content headlines and their popularity on the one hand and the regulative principle of textual efficiency on the other.

\section{Overview of research on the language of headlines}

\subsection{From traditional media to "New Media" - differences between print headlines and online headlines}

Research on newspaper language and the language of headlines in particular is abundant and provides various approaches and perspectives. Some authors (Bell, 1994; 1984, pp. 145-204) focus on the effect of the audience on the language of newspapers, while others (Kress, 1983a; 1983b) emphasize the potential power of newspapers and the language they employ to manipulate audiences. Van Dijk studies the structural and schematic aspects of news (van Dijk, 1985, pp. 69-93; 1986, pp. 155-186) and also applies a discourse analytical approach to problems such as power inequality, prejudice, ideology and racism reflected in the language of media (van Dijk, 1989, pp. 199-226; 1992, pp. 242-259; 1995a, pp. 27-45; 1995b, pp. 9-36; 1998, pp. 21-36; 1999, pp. 307-316; 2000, pp. 33-49). Crystal and Davy (1969, pp. 173-192) discuss the stylistic specificities of two newspapers on a comparative basis, whereas Lung (2000) focuses on newspaper genres.

A number of studies investigate linguistic variation from the methodological perspective of Biber's Multi-dimensional (MD) or Multi-factor corpusbased approach to studying register (Biber, 1988, 1995, 1998). These include research on the use of contractions in newspaper language done by Chafe and Danielewicz (1987), the work on relative pronouns in American newspapers done by Biesenbach-Lucas (1987, pp. 13-21), Kikai et. al. (1987, pp. 266-277), Jacobson (1989, pp. 145-154) and Olofsson (2008), as well as Louwerse et. al.'s (2004, pp. 843-848) research on variation in cohesion across spoken and written registers. Westin (Westin, 2002) offers a diachronic perspective to the study of English newspaper discourse within the MD framework, whereas Mårdh (Mårdh, 1980) focuses on newspaper headlines synchronically, while Schneider (Schneider, 2000) approaches English newspaper headlines diachronically. The methodological aspect of discourse analysis of newspaper headlines is investigated by Develotte and Rechniewski (2001).

Bulgarian researchers in the sphere of the language of New Media focus on issues such as the choice of metaphors in new media and their effects on society (Marinova, 2013; Shulikov, 2012, pp. 11-27), the effects of technology on 
language and the development of virtual communities (Grozeva, 2011; Kirova, 2007, 2010, 2013). Furthermore, there are discussions on issues of remediation and hypermediation of traditional media in a changing world (Velikova, 2009, pp. 72-91; Prodanov, 2011), the socio-representational role of New Media (Dobreva, 2011, pp. 17-30; 2012, pp. 28-63; Kaleva, 2013, pp. 37-50) and its effects on the freedom of speech (Prodanov, 2013, pp. 217-226; Pavlova, 2013, pp. 160-169).

The fact that writing for print differs considerably from writing for the New Media in general and for the Web in particular is discussed in the Bulgarian literature from the perspective of the rhetorical and stylistic specificities engendered by the changing paradigm (Antova, 2014; Dacheva, 2014; Kasabova, 2012; Mihailova, 2000; Todorova, 2013, pp. 123-128; Weiss, 2013, pp. 149-157).

Changes in the way people use language resulting from the way in which people behave (including linguistically) within the new context of the World Wide Web have received extensive treatment (Crystal, 2001; McGovern et al., 2002; Morkes, Nielsen, 1997; Morville, Rosenfeld, 2007; Nielsen, 1997, 1998, 2000, 2006, 2007a, 2007b, 2008, 2011a, 2011b, 2012; Redish, 2012). Differences due to the fact that "people behave differently when online" (McGovern et al., 2002, p. 1) strongly affect the nature of web content headlines. Nielsen (1998) claims that there are considerable differences between print headlines and online headlines because of the different way they are employed in terms of medium, context, user expectations and reading habits. In this respect, the author outlines two main differences:

\begin{abstract}
"Online headlines are often displayed out of context: as part of a list of articles, in an email program's list of incoming messages, in a search engine hitlist, or in a browser's bookmark menu or other navigation aid [...] Even when a headline is displayed together with related content, the difficulty of reading online and the reduced amount of information that can be seen in a glance make it harder for users to learn enough from the surrounding data. In print, a headline is tightly associated with photos, decks, subheads, and the full body of the article, all of which can be interpreted in a single glance. Online, a much smaller amount of information will be visible in the window, and even that information is harder and more unpleasant to read, so people often don't do so" (Nielsen, 1998).
\end{abstract}

Redish also observes that "[H]eadlines online have to do even more than headlines in print. On paper, you usually see the headline and the article together on the same piece of paper. Online and especially on a mobile, the headline often appears first by itself as a link" (2012, p. 157).

The quality of headlines is crucial as they provide the first contact and impression the user has with the content. As Orendorff (2014) points out, "[T]he headline is the most important element of any page. It isn't just your audience's first impression; sometimes it is their only impression." 
The specific behavioral patterns of web users can thus be seen as ultimately advised by a (conscious or intuitive) striving for efficiency (Iglikova, 2016, p. 204; 2017, pp. 70-74) - online people "look at headings and subheadings first; they scan for hyperlinks, numerals and keywords" (McGovern et al., 2002, p. 1). In other words, Web users value processing the largest possible amounts of content with the least possible effort and for the shortest amount of time possible in an environment so rich in information and potential candidates for their limited time and attention. This emphasizes the potential of headlines to "make or break" user experience - "[O]n the Web, you live or die by your headings (or headlines as they are called in newspapers and magazines). A good one makes it easier for readers to find your article, and much more likely that they will read what you have written" (McGovern et al., 2002, p. 5).

While headlines in print media occur along with the text they introduce (including illustrative material etc.), headlines on the web occur in isolation. They appear in a variety of contexts:

- as listed results generated by search engines such as Google, for example;

- on the homepages (start pages) and landing pages (web pages on web sites containing related links, classified and organized according to some principle - as belonging to a category within the website, as results from a search query within the website executed by the user, as being the most recently added or most frequently read, etc.); here they serve as hyperlinks to their respective content;

- on content pages, along with the actual content they refer to.

Of all three situations of occurrence of headlines on the Web, only the last one - the content page - provides users with simultaneous access to both the headline and the related content. In this case, headlines on the web resemble print headlines the most in that the information they provide is supplied and supported by the content; this means that users in this specific case can rely on an additional source of information apart from the headline itself. The presence of two simultaneously available sources of information, one of which is the actual content and the other simply serves to introduce it, would potentially lower the requirements towards the headline in terms of clarity and perspicuity, since the user has already been granted access to the body of content, and information missing in the headline can be immediately supplied.

Similarly, any existing ambiguity (intentional or not) can be immediately resolved by reference to the content. In this sense, headlines would not have to perform the function of labels and exhibit the clarity and perspicuity this function involves, due to the fact that users do not need to guess what the headline (i.e., the label) in question actually stands for. Therefore, headlines which occur in print along with the content they introduce can afford to be 
ambiguous or intentionally confusing and indeed often rely on this strategy in order to raise readers' interest and provoke particular actions on their part. This, among others, is their goal in competing with other sources of content for the attention of readers, and this is what makes them effective.

Headlines on the Web, however, occur in the aforementioned at least three different contexts and need to satisfy the specific requirements of each of those contexts. An important factor in shaping headlines is the specific nature of the World Wide Web and the ways in which the information it stores can be accessed by users. Due to the vast quantity of available content, all the information cannot be presented at once, but instead needs to be layered and accessed in stages. Regardless of the particular type of information-seeking behavior a user exhibits (Cove, Walsh, 1988, pp. 31-37; Caramel et. al., 1992, pp. 865-883; Catledge, Pitkow, 1995, pp. 1065-1073; Morville, Rosenfeld, 2006, pp. 35-38; Stolley, 2011, p. 73; Enge, 2015, pp. 41-42) they access this information via an interface in the form of the architecture and navigation of web sites. The architecture refers to the specific ways in which the available content is organized (in categories, by tagging), while the navigation provides the means for accessing the already organized content. Web site navigation includes elements such as menus, categories, links, search tools etc. These are the routes through which users access the underlying content.

Due to the specificities of the World Wide Web as a medium, the first source of information available to users about the content a particular website (or websites, if a search engine is used) offers is the headline. Before users actually reach the content itself and the contents page where it is located, they need to complete a process of selection based only on the "label" of the actual content, i.e., the headline. In this sense, users rely on headlines in their process of selection among competing alternatives (Iglikova, 2017, p. 71). As a result of this fact and its practical importance, a lot of effort has been dedicated to researching the effectiveness of headlines - i.e., what features a headline needs to possess in order to achieve the goal of its creators - attract users to the content they provide.

\subsection{Research on writing for the web. Patterns for creating web headlines}

Literature on writing for the Web (Krug, 2006; Nielsen, 2008; Redish, 2012; Stolley, 2011) proposes guidelines for creating successful texts. Literature in the field points out the importance of following these guidelines in order to compensate for the "impatience" of web users, the extremely limited resources of time and attention people are ready to spend on any piece of web content. All these guidelines are aimed at promoting processing ease, i. e. efficiency, the 
processing of the largest possible amount of content in minimum time and with minimum (physical and mental) effort.

The existence of patterns for creating headlines with analogous structures is an important means of ensuring the high quality of web headlines (Iglikova, 2017, p. 72). Patterns serve as templates or models used for creating specific headline occurrences. Firstly, these patterns include sets of constant elements which build up the basis of the pattern itself. Secondly, they have empty "slots" or positions to be filled by elements in order to produce concrete occurrences. In addition to the constant elements which build it, each pattern contains information about the structural relations among its constant as well as variable constituents. Thus, when users recognize a pattern, they can reactivate previous knowledge and experience about the processing operations this particular pattern involves and apply it to the current occurrence. Approaching actual occurrences in this manner ensures economy of processing resources which would have otherwise been necessary in establishing a new structure. Instead, users can focus only on the variables, i.e. the new elements which fill the slots provided by the recognized pattern. This way the use of patterns enhances efficiency by allowing for analogous processing of numerous actualizations and specific occurrences.

The repetitive and consistent use of patterns for creating web content headlines also enhances efficiency and processing ease as it enables the acquisition of the pattern by the user: "[W]hen users learn the structure of content and see patterns in how content is organized and accessed, they become more proficient in searching and browsing of a site" (Baehr, Schaller, 2010, p. 115).

The blank "templates" or patterns can be organized into several categories. Morrow (2012, pp. 6-8) offers the following classification:

- Threat Headlines - focusing on people's fears and apprehensions;

- Zen Headlines - promising users a solution to a problem or a (number of) way(s) to make their life easier;

- Piggyback Headlines - relying on the reputation of a famous person/ organization etc.;

- Mistake Headlines - focusing on possible mistakes people are likely to make in certain situations;

- How to Headlines - offering practical tips and instructions;

- List Headlines - promising a specific number of options for readers to consider/choose from;

- The headline classification proposed by Bly (2005, pp. 22-25) includes eight basic types:

- Direct Headlines - "state the selling proposition directly, with no wordplay, hidden meanings, or puns"; 
- Indirect Headlines - "[T]he indirect headline makes its point in a roundabout way. It arouses curiosity, and the questions it raises are answered in the body copy";

- News Headlines - "[I]f you have news about your product, announce it in the headline";

- How-to Headlines - "[H]ow-to headlines offer the promise of solid information, sound advice, and solutions to problems";

- Question Headlines - "[T]o be effective, the question headline must ask a question that the reader can empathize with or would like to see answered ... Question headlines should always focus on the reader's self-interest, curiosity, and needs";

- Command Headlines - "the first word in the command headline is a strong verb demanding action on the part of the reader";

- Reason-Why Headlines - signals a "list of ... features"; "Reason-why headlines need not contain the phrase "reason why." Other introductory phrases such as "6 ways," "7 steps," and "here's how" can do just as well";

- Testimonial Headlines - include a quote from a user; "[Q]uotation marks around the headline and the body copy signal the reader that the ad is a testimonial".

An interesting observation on the tendency for web headlines to share similar structures which lack originality (Finberg, 2011) attributes this feature partly to the efforts of online media "to manage the complexity of a 24-hour news' cycle" (a development also discussed in Bulgarian Media Studies literature, see Prodanov, 2015). As a result of these pressing specificities of the information cycle online, "many websites have template-driven publishing systems"which are essential to timely publishing but have "little flexibility" (Finberg, 2011).

\subsection{Research on virality and the efficiency of web headlines}

A study (Lee, 2014) based on 3016 headlines from 24 top content sites provides evidence regarding the most popular words and phrases featuring in the most popular headlines, i. e., the so-called "viral" headlines (see fig. 1 and fig. 2 below): 


\begin{tabular}{|c|c|c|c|c|}
\hline \multicolumn{3}{|c|}{ Most Popular Words in Viral Headlines } & \multicolumn{2}{|c|}{ Most Popular Uncommon Words } \\
\hline Words & $\#$ of uses & $\%$ & Words & \# of uses \\
\hline the & 1066 & $35 \%$ & people & 161 \\
\hline a & 866 & $29 \%$ & see & 157 \\
\hline this & 731 & $24 \%$ & one & 144 \\
\hline to & 698 & $23 \%$ & make & 143 \\
\hline you & 588 & $19 \%$ & day & 133 \\
\hline is & 501 & $17 \%$ & it's & 133 \\
\hline of & 437 & $14 \%$ & man & 120 \\
\hline in & 431 & $14 \%$ & old & 111 \\
\hline and & 394 & $13 \%$ & out & 108 \\
\hline it & 389 & $13 \%$ & dog & 107 \\
\hline what & 333 & $11 \%$ & guy & 106 \\
\hline i & 281 & $9 \%$ & new & 104 \\
\hline for & 247 & $8 \%$ & video & 104 \\
\hline that & 225 & $7 \%$ & things & 104 \\
\hline how & 214 & $7 \%$ & life & 102 \\
\hline are & 204 & $7 \%$ & made & 101 \\
\hline your & 202 & $7 \%$ & year & 100 \\
\hline on & 192 & $6 \%$ & never & 98 \\
\hline with & 175 & $6 \%$ & fac ebook & 97 \\
\hline but & 171 & $6 \%$ & awesome & 96 \\
\hline these & 161 & $5 \%$ & girl & 95 \\
\hline was & 135 & $4 \%$ & look & 95 \\
\hline from & 134 & $4 \%$ & photos & 93 \\
\hline just & 131 & $4 \%$ & love & 92 \\
\hline when & 129 & $4 \%$ & know & 88 \\
\hline will & 128 & $4 \%$ & best & 85 \\
\hline his & 128 & $4 \%$ & way & 82 \\
\hline at & 120 & $4 \%$ & thing & 82 \\
\hline an & 120 & $4 \%$ & beautiful & 81 \\
\hline why & 118 & $4 \%$ & time & 81 \\
\hline see & 117 & $4 \%$ & little & 81 \\
\hline they & 107 & $4 \%$ & more & 80 \\
\hline ever & 106 & $4 \%$ & first & 76 \\
\hline be & 106 & $4 \%$ & happened & 74 \\
\hline about & 106 & $4 \%$ & heart & 71 \\
\hline he & 105 & $3 \%$ & now & 69 \\
\hline like & 104 & $3 \%$ & you'll & 68 \\
\hline one & 99 & $3 \%$ & being & 67 \\
\hline people & 97 & $3 \%$ & ways & 67 \\
\hline not & 97 & $3 \%$ & want & 65 \\
\hline did & 97 & $3 \%$ & think & 64 \\
\hline me & 95 & $3 \%$ & something & 64 \\
\hline can & 9.5 & $3 \%$ & vears & 6.3 \\
\hline
\end{tabular}

Fig. 1 - List of most popular words in viral headlines (Lee, 2014)

Most Popular 2-Word Phrases Most Popular 3-Word Phrases Most Popular 4-Word Phrases

\begin{tabular}{|c|c|c|c|c|c|}
\hline Phrases & \# of uses & Phrases & \# of uses & Phrases & \# of uses \\
\hline this is & 114 & this is the & 22 & wait til you see & 15 \\
\hline in the & 93 & will make you & 20 & til you see what & 9 \\
\hline how to & 69 & when you see & 16 & that will make you & 9 \\
\hline is the & 55 & til you see & 16 & will blow your mind & 8 \\
\hline of the & 51 & what happens when & 15 & it looks like a & 8 \\
\hline the most & 47 & wait til you & 15 & you need to know & 7 \\
\hline what this & 44 & here are the & 13 & what happened to this & 7 \\
\hline on the & 40 & you see what & 12 & the reason why is & 7 \\
\hline when you & 39 & you need to & 12 & might look like a & 7 \\
\hline you see & 38 & this is what & 12 & is wha thappens when & 7 \\
\hline in a & 37 & that will make & 12 & for the first time & 7 \\
\hline what happened & 33 & what this guy & 11 & what he found is & 6 \\
\hline this gury & 33 & what happened to & 11 & this is what happens & 6 \\
\hline that will & 32 & like a normal & 11 & thing ive ever seen & 6 \\
\hline at the & 32 & in the world & 11 & the definitive ranking of & 6 \\
\hline to be & 31 & what he did & 10 & look like a normal & 6 \\
\hline to the & 30 & looks like a & 10 & & \\
\hline the best & 30 & İve ever seen & 10 & & \\
\hline \multirow{2}{*}{ make you } & 30 & how to make & 10 & & \\
\hline & & blow your mind & 10 & & \\
\hline
\end{tabular}

Fig. 2 - List of most popular phrases in viral headlines (Lee, 2014) 
A different study by Lai and Farbrot investigates the effect of using questions in headlines and claims that "questions in headlines are significantly more effective than declarative headlines in generating readership" (Lai, Farbrot, 2014). A study by Conductor (Safran, 2013) which isolates "the five general ways in which headlines are written" has different findings. The five "high-level headline types" include "Normal" (declarative statement) structure, question, "How to" structure, structure featuring a number and, finally, a reader-addressing structure (ibid.). When ordered according to users' preferences, these headlines achieved scores which established the "number" structure as the most popular among successful headlines ( $36 \%$ ), followed by the reader-addressing structure (21\%), the "How to" structure (17\%), the "normal" structure (15\%) and finally, in last place, the question with $11 \%$ (see fig. 3):

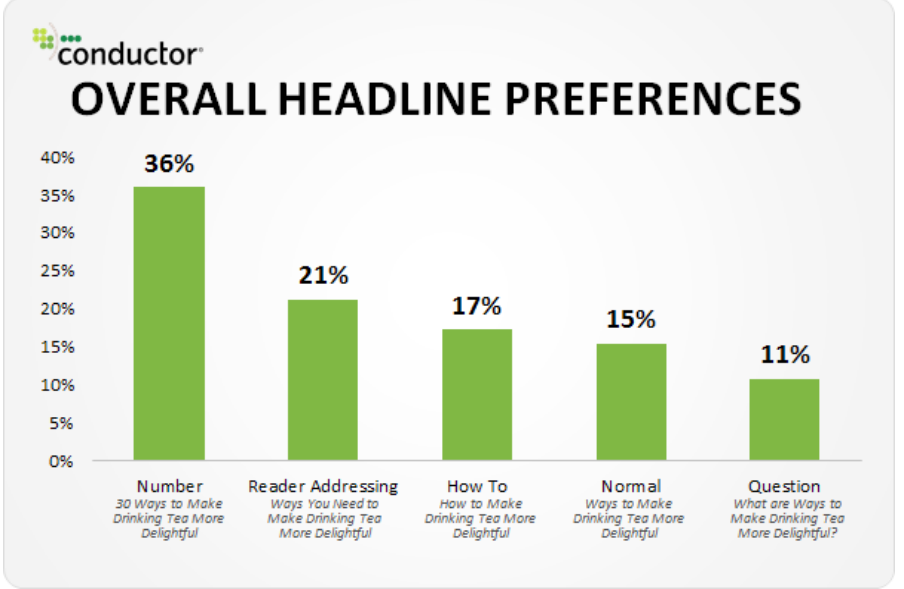

Fig. 3 - Overall headline preferences (Safran, 2013)

The same study ranked these five basic structures or patterns for creating headlines according to gender preferences. The results show that while overall preference for the five headline structure types is gender neutral, females are much more affected by numeral-containing headlines and "How to" headlines than males (a preference of $39 \%$ and $18 \%$ respectively among females opposed to the $32 \%$ and $17 \%$ among males), whereas males are more prone to click on reader-addressing headlines, normal headlines and questions $(22 \%, 17 \%$ and $12 \%$ as opposed to $20 \%, 13 \%$ and $10 \%$ respectively among females (see fig. 4): 


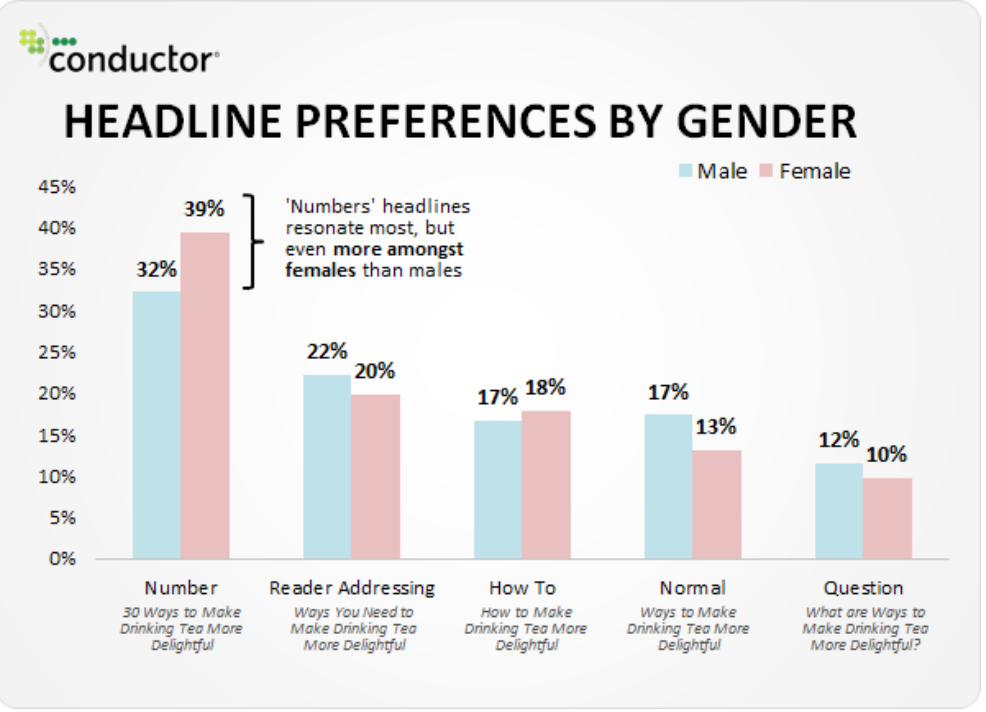

Fig. 4 - headline preferences by gender (Safran, 2013)

These findings also pertain to the adherence to the principle of efficiency in web content headlines, as the authors of the study explain the results in terms of the clarity of the headline, i. e. "the more the headline resonated, the more explicit the headline was as to what the reader was going to get out of reading the article" (Safran, 2013). This definition is synonymous with the principle of efficiency which has to do with achieving processing ease through the consistent use of patterns and the compacting of surface structure within a highly demanding context where "the modern internet user is forced to be more discerning about the headlines they click on, and is hyper cognizant of where they are investing their time" (ibid.).

Another study based on 65000 paid link titles (Bennett, 2013) compares headlines in terms of their use of positive and negative superlatives and points out the following - "compared with headlines that contained neither positive ("always" or "best") nor negative ("never" or "worst") superlatives, headlines with positive superlatives performed $29 \%$ worse and headlines with negative superlatives performed $30 \%$ better".

In line with the aforementioned findings, English-Bulgarian research on the relationship between virality and headline patterns also includes two casestudies by the author of the present article. The first one offers a comparison of headlines from 3 different websites in terms of the specific numerals used and their frequency of occurrence and aims at providing an interlinguistic, comparative aspect to the analysis of numerals and the phenomenon of virality (Iglikova, 2016, pp. 203-211). The second case study is a comparative, corpus- 
based case study of the patterns employed in English-language and Bulgarianlanguage viral headlines pertaining to one particular topic (the taste of Coca-Cola at McDonald's) and provides a descriptive analysis of a specific phenomenon and a comparison of the approaches to creating headlines on English-language websites on the one hand, and on Bulgarian websites, on the other (Iglikova, 2017, pp. 71-84).

\section{Conclusion}

The relevance and growing importance of integrating research from various fields dealing with the language of New Media in general and the language of headlines on the web is undeniable. It has to do with the multifaceted nature of the World Wide Web and its transformation of various kinds of traditional media. For this purpose, the present article attempts to offer an overview of available research concerning the topic and in this way to enable certain continuity and consistency of further research. The article also provides an overview of Bulgarian research on the topic, which is deemed to be necessary for the integration of local, cultural- and language-specific findings within the overall global picture of "digitally born" texts online.

\section{References:}

Antova, D. (2014). Retorichni ezikovi osobenosti v zaglaviyata na publikatsiite v blogovete na Ivo Indzhev i Ivan Bedrov. In D. Antova (Ed.), Retorika i kominikatsii. Lingvistika, komunikatsii, retorika. Vol 14.

Baehr, C., \& Schaller, B. (2010). Writing for the Internet. A guide to real communication in virtual space. Santa Barbara, California: Greenwood Press.

Bell, A. (1984). Language style as audience design. Language in Society, Vol. 13, No. 2. Cambridge University Press. 145-204.

Bell, A. (1994). The Language of news media. Oxford: Blackwell Publishers, Ltd.

Bennett, A. (2013). "Headlines: When the best brings the worst and the worst brings the best". Retrieved from: http:/www.outbrain.com/blog/2013/07/headlines-when-the-bestbrings-the-worst-and-the-worst-brings-the-best.html

Bly, R. W. (2005) The copywriter's handbook. $3^{\text {rd }}$ edition. New York: Henry Holt and Company, LLC.

Biber, D. (1988). Variation across speech and writing. Cambridge: Cambridge University Press.

Biber, D. (1995). Dimensions of register variation: A cross-linguistic comparison. Cambridge: Cambridge University Press.

Biber, D., Conrad, S., \& Reppen, R. (1998). Corpus linguistics: Investigating language structure and use. Cambridge: Cambridge University Press.

Biesenbach-Lucas, S. (1987). The use of relative markers in Modern American English. In K. M. Denning, S. Inkelas, F. C. Mc Nair-Knox, \& J. R. Rickford. (Eds.), Variation in 
language: NWAV-XV at Stanford. Stanford, CA: Department of Linguistics, Stanford University. (pp. 13-21).

Chafe, W., \& Danielewicz, J. (1987). Properties of spoken and written language. In R. Horowitz, \& S. J. Samuels (Eds.) Comprehending oral and written language (pp. 83113). New York: Academic Press.

Crystal, D. (2001). Language and the Internet. Cambridge: Cambridge University Press.

Dacheva, G. (2014). Stylistic effects of the titles from Bulgarian and French journals. Part 2. In G. Dacheva (Ed.), Retorika i kominikatsii. Lingvistika, komunikatsii, retorika. Vol 14.

Develotte, C., \& Rechniewski, E. (2001). Discourse analysis of newspaper headlines: A methodological framework for research into national representations. Web Journal of French Media Studies. Vol.1, Issue 1.

Dobreva, E. (2011). Kakvo i kak pishat vestnitsite za narkotitsite. Episkop-Konstantinovi Cheteniya. Vol 16. Shumen: Konstantin Preslavsky University Press. 17-30.

Dobreva, E. (2012). Informatsionnoto obshtestvo i negovata reprezentatsiya v audiovizualnata reklama". Masovite komunikatsii v informatsionnoto onshtestvo. Seriya Obshtestveni komunikatsii. Vol 2. Shumen: Konstantin Preslavsky University Press. 2863.

Finberg, H. (2011). How headlines can help. Retrieved from http://www.poynter.org/ uncategorized/21408/how-headlines-can-help/

Iglikova, R. (2017). Headline patterns in viral web content - English-Bulgarian comparative case study. In Todorova et al. (Eds.). Crossing Borders and Bridging Gaps in English Language Teaching and Research. Series in Linguistics, Culture and FLT, issue 2. Assenevtsi. 71-84.

Iglikova, R. (2016). What's your number? - Numeral preference in viral headlines from 3 websites. Lyuboslovie. Shumen: Konstantin Preslavsky University Press, vol. 16, 203211.

Jacobson, S. (1989). Some grammatical trends in american newspaper language. In L. E. Breivik, A. Hille, \& S. Johansson (Eds.). Essays on English language in honour of Bertil Sundby, (pp. 145-154). Oslo: Novus forlag.

Kaleva, S. (2013). Pretsedentnite fenomeni vuv virtualniya politicheski diskurs. EpiskopKonstantinovi Cheteniya, Vol. 19. Shumen: Konstantin Preslavsky University Press. 3750.

Kasabova, I. (2012). Medii i novi medii - promyana na retoricheskata paradigma. Definirane i predefinirane na ponyatiya. Retorika i Komunikatsii. Issue 5.

Kikai, A., Schleppergrell, M., \& Tagliamonte, S. (1987). The influence of syntactic position on relativization strategies. In K. M. Denning, S. Inkelas, F. C. Mc Nair-Knox, \& J. R. Rickford (Eds.), Variation in language: NWAV-XV at Stanford. Stanford, CA: Department of Linguistics, Stanford University. 266-277.

Kirova, L. (2007). Kompyuturnite tehnologii i bulgarskiyat ezik. Sofia: SemaRSh.

Kirova, L. (2010). Ezikut na BG info pokolenieto. Sofia: Galik.

Kirova, L. (2013). Virtualnite obshtnosti v kompyuturno-oposredstvanata komunikatsiya dnes. Sotsialnite mrezhi. Retorika i komunikatsii. Issue 9.

Kress, G. (1983a). Linguistic and ideological transformations in newspaper language. In H. Davis, \& P. Walton (Eds.), Language, image and the media. Oxford: Blackwell. 
Kress, G. (1983b). The politics of newspaper language. International Journal of the Sociology of Language. Vol. 32.

Lai, L., \& Farbrot, A. (2014). What makes you click? The effect of question headlines on readership in computer-mediated communication. Social Influence. Vol 9 (4).

Lee, K. (2014). How to write the perfect headline: The top words used in viral headlines. Retrieved from: http://www.blog.bufferapp.com/the-most-popular-words-in-most-viralheadlines

Louwerse, M., McCarthy, P., McNamara, D. S., \& Graesser, A. (2004). Variation in language and cohesion across written and spoken registers. In K. Forbus, D. Gentner, \& T. Regier (Eds.), Proceedings of the 2th annual meeting of the cognitive science society. Mahwah, NJ: Erlbaum. 843-848.

Lung, M. (2000). Newspaper genres and newspaper English. In F. Ungerer (Ed.) English media texts past and present. Language and textual structure. Amsterdam/Philadelphia: John Benjamins Publishing Company. 131-149.

Mårdh, I. (1980). Headlinese: On the Grammar of Emglish front page headlines. Malmo: CWK Gleerup.

Marinova, E. (2013). Zhurnalisticheskite metafori v informatsionnoto obshtestvo. Lichna svoboda i medii. Seriya Obshtestveni komunikatsii. Vol. 3. Shumen: Faber. 217-226.

McGovern, G., Norton, R., \& O’Dowd, C. (2002). The web content style guide. An essential reference for online writers, editors and managers. London: Financial Times Prentice Hall.

Mihailova, N. (2000). Internet-minimizatsiya na ezika. Liternet Electronic Journal. Issue 8 (9). Retrieved from: http://liternet.bg/publish/nimihailova/inet.htm

Morkes, J., \& Nielsen, J. (1997). Concise, scannable, and objective: How to write for the web. Retrieved from: http://www.nngroup.com/articles/concise-scannable-andobjective-how-to-write-for-the-web/

Morville, P., \& Rosenfeld, L. (2007). Information architecture for the world wide web. $3^{\text {rd }}$ edition. USA: O’Reilly Media, Inc. 26-28.

Nielsen, J. (1995). Multimedia and hypertext. The Internet and beyond. Mountain View, CA: Academic Press.

Nielsen, J. (1997). Be succinct! (Writing for the web). Retrieved from: http://www.nngroup. com/articles/be-succinct-writing-for-the-web/

Nielsen, J. (1998). Microcontent: How to write headlines, page titles, and subject lines. Retrieved from: http://www.nngroup.com/articles/microcontent-how-to-writeheadlines-page-titles-and-subject-lines/

Nielsen, J. (2000). Eyetracking study of web readers. Retrieved from: http://www.nngroup. com/articles/eyetracking-study-of-web-readers/

Nielsen, J. (2006). F-Shaped pattern for reading web content. Retrieved from: http://www. nngroup.com/articles/f-shaped-pattern-reading-web-content/

Nielsen, J. (2007a). Blah-Blah text: Keep, cut, or kill? Retrieved from: http://www.nngroup. com/articles/blah-blah-text-keep-cut-or-kill/

Nielsen, J. (2007b). Long vs. short articles as content strategy. Retrieved from: http://www. nngroup.com/articles/content-strategy-long-vs-short/ 
Nielsen, J. (2007c). Show numbers as numerals when writing for online readers. Retrieved from: http:/www.nngroup.com/articles/web-writing-show-numbers-as-numerals/

Nielsen, J. (2008). Writing style for print vs. web. Retrieved from: http://www.nngroup. com/articles/writing-style-for-print-vs-web/

Nielsen, J. (2011a). International usability: Big stuff the same, details differ. Retrieved from: http://www.nngroup.com/articles/intarnational-ussability-details-differ/

Nielsen, J. (2011b). Top 10 mistakes in web design. Retrieved from: http://www.nngroup. com/articles/top-10-mistakes-web-design/

Nielsen, J. (2012). Usability 101: Introduction to usability. Retrieved from: http://www. nngroup.com/articles/usability-101-introduction-to-usability/

Olofsson, A. (2008). Half a century of relative monitoring. The 1959 which-hunt in scientific American. Moderna Sprak. Vol. 102, Issue 2.

Orendorff, A. (2014). The ultimate copy checklist: 51 questions to optimize every element of your online copy. Retrieved from: http://www.copyblogger.com/optimize-online-copy/

Pavlova, I. (2013). Moderatorat, svobodata na slovoto i novite medii. Lichna svoboda $i$ medii. Seriya Obshtestveni komunikatsii. Vol. 3. Shumen: Faber. 160-169.

Prodanov, Y. (2011). Pechatniyayt vestnik prez ekrana na prerazhdaneto. Izsledvane na Mediite. Seriya Obshtestveni Komunikatsii, Vol 1. Shumen: Konstantin Preslavsky University Press.

Prodanov, Y. (2013). Komersialnite medii I byagstvoto ot svobodata. Lichna svoboda $i$ medii. Seriya Obshtestveni komunikatsii. Vol. 3. Shumen: Faber. 217-226.

Prodanov, Y. (2015). Novi medii i obshtestveno (sa)mnenie. Retrieved from: http://www. librev.com/index.php/discussion-culture-publisher/2850-2015-11-17-09-11-26

Schneider, K. (2000). The emergence and development of headlines in British newspapers. F. Ungerer (Ed.), English media texts past and present. Language and textual structure (pp. 45-66). Amsterdam/Philadelphia: John Benjamins Publishing Company.

Shulikov, P. (2012). Informatsionnoto obshtestvo kato industriya na metaforite. Masovite komunikatsii v informatsionnoto obshtestvo. Seriya Obshtestveni komunikatsii. Vol. 2. 11-27.

Todorova, D. (2013). Onlain vestnika - kasata pamet. Episkop-Konstantinovi Cheteniya. Vol. 19. Shumen: Konstantin Preslavsky University Press. 123-128.

van Dijk, T. (1985). Structures of news in the press. In T. van Dijk (Ed.), Discourse and communication, (pp. 69-93). Berlin: De Gruyter.

van Dijk, T. (1986). News schemata. In S. Greenbaum, \& C. R. Cooper (Eds.) Studying writing. Linguistic approaches, (pp. 155-186). Beverly Hills, CA: Sage.

van Dijk, T. (1989). Mediating racism. The role of the media in the reproduction of racism. In R. Wodak (Ed.), Language, power and ideology, (pp. 199-226). Amsterdam/ Philadelphia: John Benjamins Publishing Company.

van Dijk, T. (1992). Racism and argumentation: 'Race riot' rhetoric in tabloid editorials. In van Eemeren et al. (Eds.) Argumentation illuminated, (pp. 242-259). Dordrecht: Foris.

van Dijk, T. (1995a). The mass media today. Discourses of domination or diversity? Javnost/The Public. Ljubljana. Vol. 2. Issue 2. 27-45.

van Dijk, T. (1995b). Power and the news media. In D. Paletz (Ed.), Political communication and action. Cresskill, NJ: Hampton Press. 9-36. 
van Dijk, T. (1998). Opinions and ideologies in the press. In A. Bell, \& P. Garrett (Eds.) Approaches to media discourse, (pp. 21-63). Oxford: Blackwell.

van Dijk, T. (1999). Media, racism and monitoring. In K. Nordenstreng, \& M. Griffin (Eds.), International Media Monitoring, (pp. 307-316). Cresskill, NJ: Hampton Press.

van Dijk, T. (2000). New(s) racism: A discourse analytical approach. In S. Cottle (Ed.), Ethnic minorities and the media, (pp. 33-49). Milton Keynes, UK: Open University Press.

Velikova, S. (2009). Novite medii v promenyashtata se publichna sfera. Lyuboslovie, Vol. 10. Shumen: Konstantin Preslavsky University Press. 72-91.

Weiss, K. (2013). Informativnost $\mathrm{i}$ otsenachnost v zaglaviyata na tri nemski vestnika. Episkop-Konstantinovi cheteniya, Vol. 19. Shumen: Konstantin Preslavsky University Press. 149-157.

Westin, I. (2002). Language change in English newspaper editorials. Amsterdam: Rodopi. 